\title{
Effects of rice bran on growth and survival of Thai sharpunti Barbodes gonionotus in earthen ponds
}

\author{
M. Moniruzzaman ${ }^{1}$ and M. F. A. Mollah ${ }^{2}$ \\ ${ }^{1}$ Bangladesh Fisheries Research Institute, Brackishwater Station, Paikgacha, Khulna-9280 and ${ }^{2}$ Department of \\ Fisheries Biology \& Genetics, Bangladesh Agricultural University, Mymensingh-2202, Bangladesh and
}

\begin{abstract}
An experiment was carried out with Barbodes gonionotus for 4 months (120 days) in the experimental ponds of size of 2.8 decimal each with the same stocking densities of $57 \mathrm{fish} / \mathrm{dec}$. in all the treatments. Each pond was divided into two equal halves by synthetic net fixed with bamboo. Three treatments $\left(T_{1}, T_{2}\right.$ and $\left.T_{3}\right)$ each with two replicates were used. The fish were reared in only fertilized pond $\left(T_{1}\right)$, in fertilized and rice bran fed pond $\left(T_{2}\right)$ and only rice bran fed pond $\left(T_{3}\right)$. During the study period the water quality parameters such as temperature, transparency, water depth, dissolved oxygen, $\mathrm{pH}$ and plankton biomass in all treatments were within productive range. The observed growth parameters such as mean weight gain were $36.24 \mathrm{~g}, 65.85 \mathrm{~g}$ and $44.41 \mathrm{~g}$, percent weight gain were $120.80 \%$, $219.52 \%$ and $148.03 \%$, the average daily gain were $1.28 \mathrm{~g}, 2.37 \mathrm{~g}$ and $1.64 \mathrm{~g}$, the specific growth rate were $0.66 \%$, $0.97 \%$ and $0.77 \%$, in $\mathrm{T}_{1}, \mathrm{~T}_{2}$ and $\mathrm{T}_{3}$ respectively. The gross total productions of Sharpunti were $844.64,1292.85$ and $930.36 \mathrm{~kg} / \mathrm{ha} / 120$ days. The net productions were $462.49,888.39$ and $555.35 \mathrm{~kg} / \mathrm{ha} / 120$ days in $\mathrm{T}_{1}, \mathrm{~T}_{2}$ and $\mathrm{T}_{3}$ respectively. The gross and net total productions in $T_{2}$ were highest compared to $T_{1}$ and $T_{3}$. Sharpunti showed highest growth performance in $\mathrm{T}_{2}$ when fine rice bran was used as feed and simultaneously the pond was fertilized.
\end{abstract}

Keywords: Rice bran, Growth, Survival, Thai sharpunti

\section{Introduction}

Fish production in a water body is largely dependent upon the basic fertility of the water body and the supply of supplementary feeds. The intensive fish culture depends to a large extent on supplementary feeding (Balarin and Haller, 1982).

The production of fish in our country is very low compared to other countries of the world due to lack of technical knowledge and proper management practices. Bangladesh is facing today the problem of protein caloric malnutrition. This protein deficiency is becoming more and more acute because of the tremendous population growth without any significant increase in animal production. To meet up this acute animal protein shortage of the country the present production level has to be increased to manifolds. This can be achieved by bringing all the water bodies under improved fish culture and management practices (Monju, 1996).

All the vital functions of fish like feeding, digestion, assimilation, growth, responses to stimuli and reproduction are dependent on water quality. Limnological works have been carried out in different areas of the world to have some knowledge about the water quality and its limiting and optimum range of aquatic organisms. For improved fish culture it is also imperative to know how feeds are related to growth and survival for profit maximization. Therefore, the present experiment was designed to ascertain the effects of rice bran on growth and survival of Thai Sharpunti Barbodes gonionotus in the traditional small earthen ponds.

\section{Materials and Methods}

Study area: The experiment was conducted from $1^{\text {st }}$ January to $30^{\text {th }}$ April 2006 (120 days) to observe the effect of different feed ingredients on the production performance of Thai Sharpunti, Barbodes gonionotus

To study the growth rate, survival rate and production potential of $B$. gonionotus, three treatments were used in the experiment, each pond (2.8 decimal) with two replications was divided into two by fencing right at the middle by the help of synthetic durable nets and bamboos. The six segments of 3 ponds were used for this experiment feeding with supplementary feed like fine mesh rice bran. Stocking density remained same in all treatments viz. 57 fish/dec. (Table 1). 
Table 1. Experimental design

\begin{tabular}{|c|c|c|c|c|}
\hline Treatment & Pond & Replication & Feed ingredients & $\begin{array}{c}\text { Stocking density } \\
\text { (fish/decimal) }\end{array}$ \\
\hline $\mathrm{T}_{1}$ & 1 & 2 & Fertilizer & 57 \\
\hline $\mathrm{T}_{2}$ & 2 & 2 & Fertilizer + Rice bran & 57 \\
\hline $\mathrm{T}_{3}$ & 3 & 2 & Rice bran & 57 \\
\hline
\end{tabular}

In treatment- 1 under fertilized (inorganic and organic) condition In treatment- 2 feeding with rice bran under fertilized condition In treatment- 3 feeding with only rice bran

Pond preparation: All the ponds were dried by draining out the water with a dewatering pump. Lime was applied at a rate of $1 \mathrm{~kg}$ per decimal. Lime was liquefied into an earthen pot then applied by spreading homogeneously on the pond bottom. After one week ponds were filled with water and urea and TSP were applied at the rate of $200 \mathrm{~g}$ and $100 \mathrm{~g}$ per decimal respectively.

Stocking: The ponds were stocked with same densities. Eighty fish were released in each pond segment (1.4 decimal in size). The ponds were stocked randomly with the fish of average size $30 \pm 0.05 \mathrm{~g}$. The length and weight of fish were recorded before releasing them. Feeding began just after stocking.

Feed supply: Feed was provided at the rate of $5 \%$ of the total biomass. In $T_{1}$ ponds were fed with only fertilizer (200 g Urea $+100 \mathrm{~g} \mathrm{TSP}$ and $1 \mathrm{~kg}$ cow dung per segment/7 days) during the experimental period. Ponds under $T_{2}$ and $T_{3}$ were fed with fertilizers and rice bran and only rice bran respectively at the same rate. Fortnightly growth was monitored in each pond to adjust the feeding rate. The fish were fed twice daily at $08 \mathrm{~h}$ and $17 \mathrm{~h}$.

Sampling procedure: Sampling was done every fifteen days interval. Stocked $10 \%$ sharpunti were sampled from each of the pond in the morning (from 08h to 09h) by using seine net. The length of the body of each fish sample were measured in centimeters $(\mathrm{cm})$ while weight of the fish were measured in nearest gram ( $\mathrm{g}$ ) by using measuring scale and electronic balance (Metler PM 480) respectively.

Water quality parameters: The water quality parameters such as water depth, transparency, temperature, dissolved oxygen (DO) and $\mathrm{pH}$ were monitored fortnightly throughout the experimental period. Water temperature of the ponds was measured with the help of Celsius thermometer. Dissolved oxygen of the pond water was measured by using an oxygen meter (Oxymeter WTW, Multi 340i). Electronic pH meter (Jenway, model 3020, UK) was used to measure the pH of water. Water transparency and depth were measured by using secchidisc and weighted measuring tape respectively. All analysis was done in the Water Quality and Pond Dynamics Laboratory of the Faculty of Fisheries, Bangladesh Agricultural University, Mymensingh.

\section{Plankton biomass}

Collection, preservation and enumeration of plankton: Plankton samples were collected fortnightly from experimental ponds. Ten litre samples of pond water were collected from different areas and depth of the pond and filtered through a fine meshed $(25 \mathrm{~mm})$ phytoplankton net. Filtered sample was taken into a measuring cylinder and carefully made up to standard volume with distilled water. Using plastic tubing, water was siphoned off from the measuring cylinder and plankton were concentrated into $50 \mathrm{ml}$ and preserved using $5 \%$ buffered formalin in small plastic vials for subsequent studies. From each $10 \mathrm{ml}$ preserved sample, $1 \mathrm{ml}$ subsample was examined using Sedgwick-Rafter cell (S-R cell) and binocular microscope (Olympus BH2).

Counting: The S-R counting cell is a special type of slide having a counting chamber which is $50 \mathrm{~mm}$ long, $20 \mathrm{~mm}$ wide and $1 \mathrm{~mm}$ deep; the volume of the chamber is $1 \mathrm{ml}$. The counting chamber is equally divided into 100 fields, each having a volume of $0.01 \mathrm{ml}$. 
Calculation: Calculation of plankton samples were done by using the following formula (Rahman, 1992).

$$
N=\frac{A \times 100 \times C}{V \times F \times L}
$$

Where,

$\mathrm{N}=$ No. of plankton cells or units per litre or original water

$A=$ Total no. of plankton counted

$\mathrm{C}=$ Volume of final concentrate of the sample in $\mathrm{ml}$.

$V=$ Volume of a field $=1 \mathrm{~mm}^{3}$

$\mathrm{F}=$ No. of fields counted

$\mathrm{L}=$ Volume of original water in litre

Harvesting of Thai Sharpunti: After 4 months of rearing, the fishes were harvested on 120 days. After harvesting by seine net all fishes were counted and weighed individually for each pond to assess the survival rate and production.

Analytical methods: The proximate composition of feed ingredient was analyzed in triplicate according to standard procedures given by Association of Official Analytical Chemists (AOAC, 1980).

Moisture $(\%)=\frac{\text { Original sample weight }- \text { dried sample weight }}{\text { Original sample weight }} \times 100$

Crude protein $=6.25 \times \%$ Nitrogen

$\%$ Nitrogen $=\frac{\text { Milliequivalent of nitrogen }(0.014) \times \text { titrant value }(\mathrm{ml}) \times \text { strength of } \mathrm{HCl}}{\text { Sample weight }(\mathrm{g})} \times 100$

Crude lipit $(\%)=\frac{\text { Weight of lipid }(\mathrm{g})}{\text { Weight of sample }(\mathrm{g})} \times 100$

Ash content $(\%)=\frac{\text { Weight of ash }(g)}{\text { Weight of sample }(g)} \times 100$

Crude fibre $(\%)=\frac{\text { Weight of sample after air drying }(\mathrm{g})-\text { weight of sample after ashing }(\mathrm{g})}{\text { Weight of sample }(\mathrm{g})} \times 100$

Nitrogen free extract $(\mathrm{NFE})=100-\%$ (moisture + protein + lipid + ash + crude fibre $)$

Analysis of the experimental data

Experimental data collected during the growth trial in different treatment were evaluated by using the following parameters.

Growth parameters

a) Weight gain $(\mathbf{g})=$ mean final fish weight $(\mathrm{g})$ - mean initial fish weight $(\mathrm{g})$

b) Percent weight gain $=\frac{\text { Mean final fish weight }- \text { Mean initial fish weight }}{\text { Mean initial fish weight }} \times 100$ 
c) SGR $(\% /$ day $)=\frac{\log _{2}-\log _{1}}{\text { Time }} \times 100$

Where,

$\mathrm{W}_{1}=$ Initial live body weight $(\mathrm{g})$ at time $\mathrm{T}_{1}$ (day)

$\mathrm{W}_{2}=$ Final live body weight $(\mathrm{g})$ at time $\mathrm{T}_{2}$ (day)

\section{d) Average daily gain (g)}

$A D G=\frac{\text { Mean final fish weigh }- \text { Mean initial fish weight }}{T_{2}-T_{1}}$

\section{e) Cumulative weight gain (g)}

CWG $=$ Mean final fish weight

Statistical analysis: Duncan's new multiple range test (DMRT) and one-way analysis of variance (ANOVA) were used to determine the effect of different feeds on the growth of fish to identify the $1 \%$ level of significance of variance among the treatment means. Standard deviations $( \pm S D)$ of treatment means were also calculated.

\section{Results and Discussion}

\section{Water quality parameters}

In the present study, water quality parameters were found to range within good and normal aquaculture condition. The water quality parameters remained more or less similar. Not very large discrimination was seen among them (Table 2; Figs. 1a to 1e).

Table 2. Comparisons of water quality parameters (mean \pm SD) among three treatments by using ANOVA

\begin{tabular}{|c|c|c|c|c|c|}
\hline Parameters & Treatment- 1 & Treatment- 2 & Treatment- 3 & F- value & $\begin{array}{c}\text { Level of } \\
\text { significance }\end{array}$ \\
\hline Temperature $\left({ }^{0} \mathrm{C}\right)$ & $29.73 \pm 0.14$ & $29.75 \pm 0.86$ & $29.74 \pm 0.50$ & 0.106 & NS \\
\hline Transparency $(\mathrm{cm})$ & $37.99 \pm 1.91$ & $30.88 \pm 1.80$ & $36.06 \pm 0.74$ & 10.91 & NS \\
\hline Water depth $(\mathrm{cm})$ & $151.94 \pm 2.07$ & $144.86 \pm 0.39$ & $150.64 \pm 2.54$ & 7.85 & NS \\
\hline DO $(\mathrm{mg} / \mathrm{L})$ & $4.41 \pm 0.67$ & $4.63 \pm 0.44$ & $4.51 \pm 0.14$ & 2.82 & NS \\
\hline $\mathrm{pH}$ & $7.25 \pm 0.58$ & $7.41 \pm 0.57$ & $7.28 \pm 0.03$ & 7.69 & $\mathrm{NS}$ \\
\hline Plankton biomass & $50.80 \pm 3.68^{\mathrm{a}}$ & $56.15 \pm 2.38^{\mathrm{b}}$ & $52.98 \pm 5.27^{\mathrm{b}}$ & 62.26 & ${ }^{\star *}$ \\
\hline
\end{tabular}

Plankton biomass $=$ no. $\times 10^{5}$ cell/l

NS indicates non significant at $1 \%$ level.

Figures in the same row with same letters are not significantly different $(P>0.01)$

Temperature $\left({ }^{\circ} \mathrm{C}\right)$ : The mean values of water temperature were $29.73 \pm 0.14,29.75 \pm 0.86$ and $29.74 \pm$ $0.50{ }^{\circ} \mathrm{C}$ in $\mathrm{T}_{1}, \mathrm{~T}_{2}$ and $\mathrm{T}_{3}$ respectively (Table 2, Fig.1a). Dewan (1973) recorded temperature range of 19.0$35.0^{\circ} \mathrm{C}$ from a pond situated at Mymensingh.

Transparency $(\mathbf{c m})$ : Transparency recorded in this experiment were $37.99 \pm 1.91,30.88 \pm 1.80$ and $36.06 \pm 0.74 \mathrm{~cm}$ in the $T_{1}, T_{2}$ and $T_{3}$ respectively. The highest and lowest transparency of water bodies were $45.52 \mathrm{~cm}$ and $24.23 \mathrm{~cm}$ in the month of January and March in $T_{1}$ and $T_{2}$ (Table 2, Fig.1b). Keilhorn (1952) reported that transparency of water was affected by microscopic organisms, suspended organic matter and heavy plankton growth. 


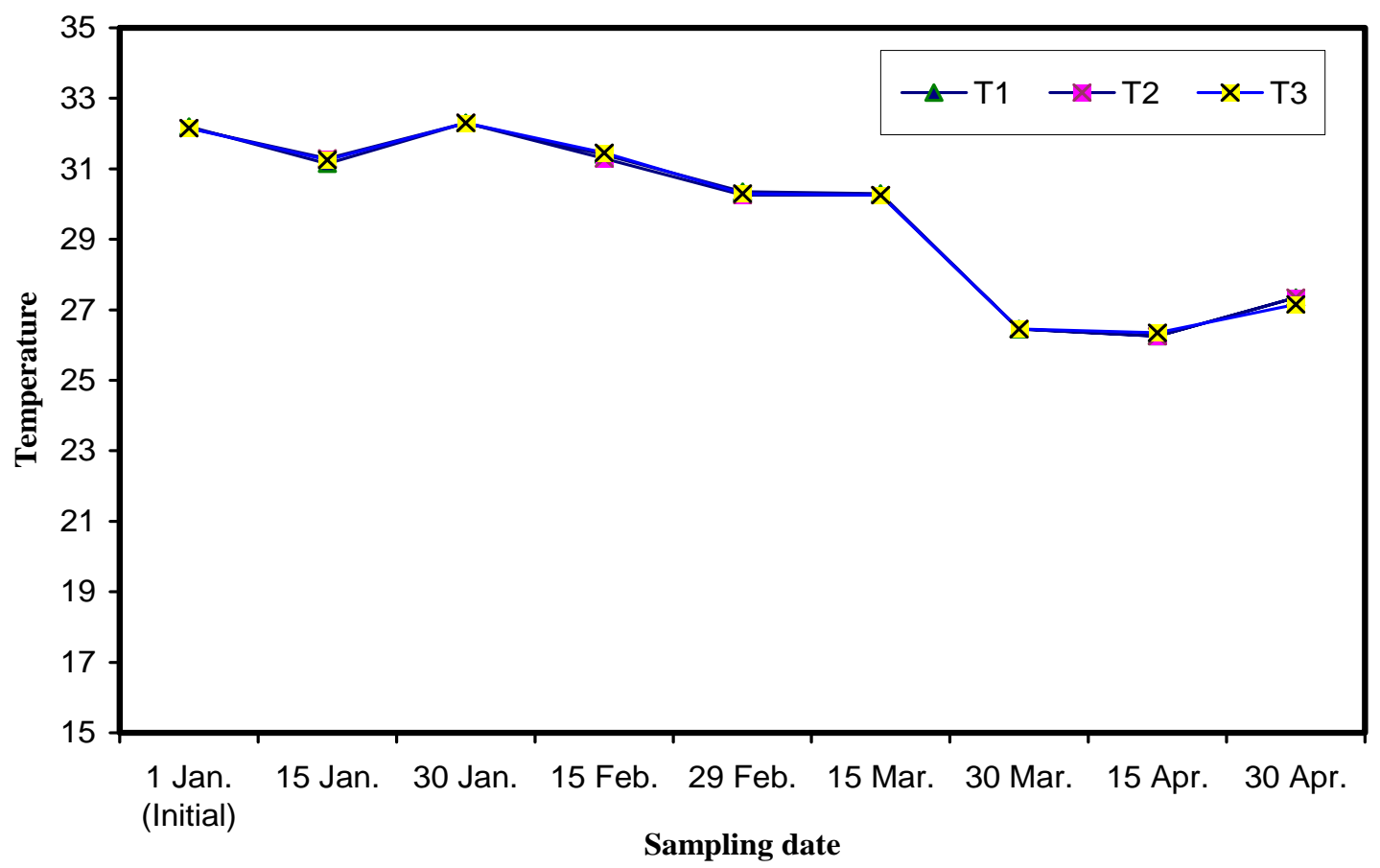

Fig. 1a. Showing the variations of temperature $\left({ }^{\mathrm{O}} \mathrm{C}\right)$ under three treatments

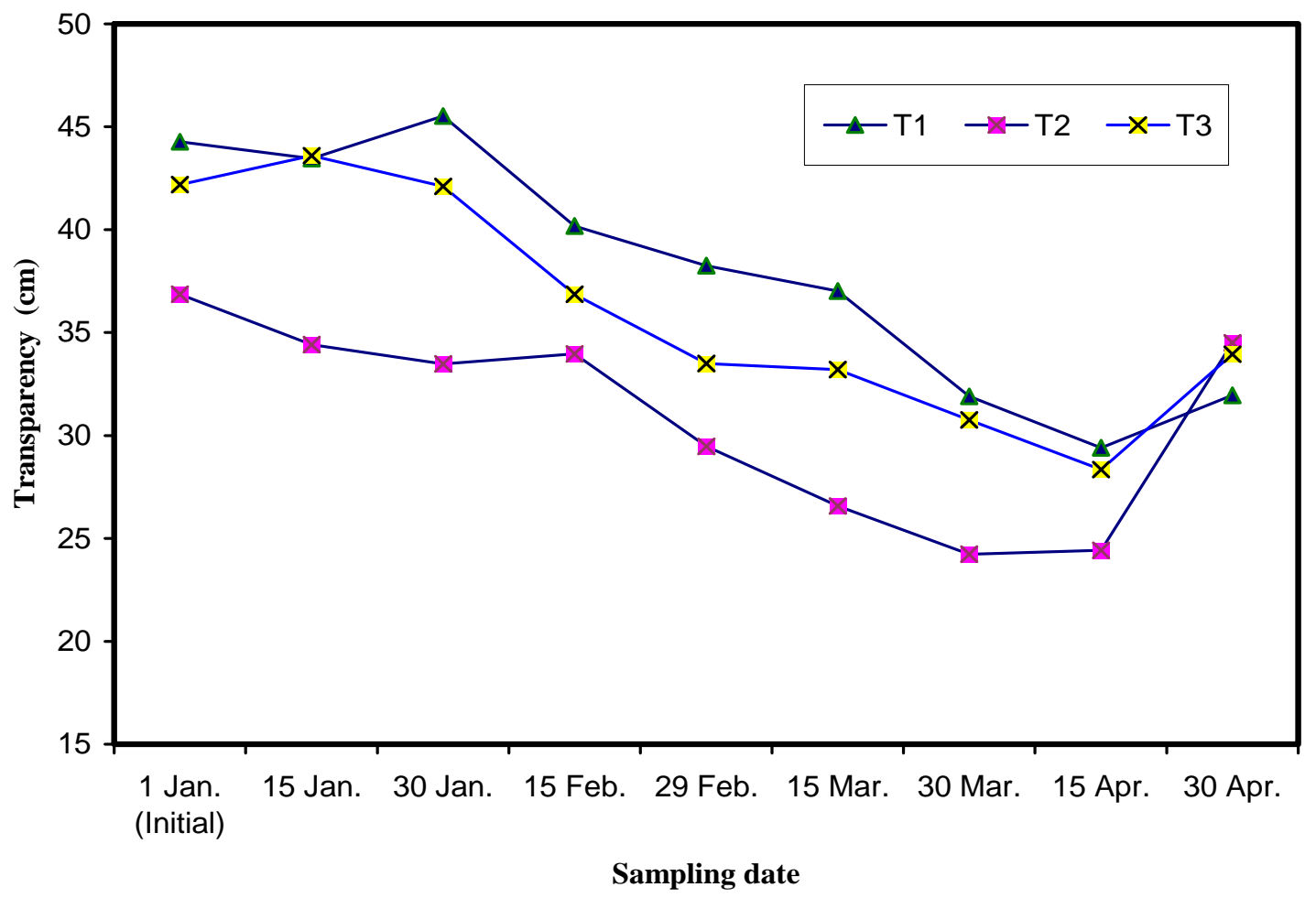

Fig. 1b. Showing the variations of transparency $(\mathrm{cm})$ under three treatments 
Water depth (cm): Water depth were $151.94 \pm 2.07,144.86 \pm 0.39$ and $150.64 \pm 2.54 \mathrm{~cm}$ in the $T_{1}, T_{2}$ and $T_{3}$ respectively. The highest and lowest water depths were 155.38 and $134.98 \mathrm{~cm}$ during the month of April in the $T_{3}$ and $T_{2}$ respectively (Table 2, Fig.1c). There was no significant change of water level during the experiment.

Dissolved oxygen (mg/l): Dissolved oxygen were $4.41 \pm 0.67,4.63 \pm 0.44$ and $4.51 \pm 0.14 \mathrm{mg} / \mathrm{ln} \mathrm{T}_{1}, \mathrm{~T}_{2}$ and $T_{3}$ respectively (Table 2, Fig.1d). Alikunhi (1957) stated that good pond water for fish cultivation should have a fair amount of dissolved oxygen ranging from 5 to $7 \mathrm{ppm}$. Benerjea (1967) considered 5.0 to $7.0 \mathrm{mg} / \mathrm{L}$ dissolved oxygen content of water to be fair or good in respect of productivity. Sreenivasan (1976) reported that high rate of decomposition of organic matter decreases the oxygen content in the bottom. Ali et al. (1982) observed DO values of 7.2-10.5 mg/L throughout the period of investigation in freshwater pond. On the other hand, Rahman et al. (1982) measured DO values of $0.40-8.8 \mathrm{mg} / \mathrm{L}$. The result showed an inverse relationship of dissolved oxygen content with temperature. Coche (1967) observed an increase in dissolved oxygen content with the decrease of temperature.

pH: The values of pH were $7.25 \pm 0.58,7.41 \pm 0.57$ and $7.28 \pm 0.03$ in $T_{1}, T_{2}$ and $T_{3}$ respectively. The highest and lowest pH values were found to be 7.90 and 6.71 in the month of January and April in $T_{2}$ and $\mathrm{T}_{1}$ respectively (Table-2, Fig.1e).

\section{Plankton biomass}

Plankton biomass in the present study was more or less similar in $T_{1}$ and $T_{3}$ but comparatively higher in $\mathrm{T}_{2}$. It may be due to the excreta of sharpunti, fertilization and effect of uneaten rice bran. Plankton biomass was $50.80 \pm 3.68,56.15 \pm 2.38$ and $52.98 \pm 5.27$ in the $T_{1}, T_{2}$ and $T_{3}$ respectively (Table-2, Fig.1f). The highest and lowest plankton number was recorded to be $58.50 \times 10^{5} / /$ and $50.65 \times 10^{5} / /$ during the months of February and April in the $\mathrm{T}_{2}$ and $\mathrm{T}_{3}$ respectively. The colour of pond water was more or less greenish for couple of months but it became turbid because of vigorous movement of growing fishes and searching of foods which might cause low values of oxygen. It might be caused due to reduction of photosynthetic activities by plant during the days of less sunlight. Islam et al. (1996) recorded maximum phytoplankton in June-July and October which also agreed with the findings of present study.

\section{Growth parameters}

Fortnightly growth parameters of Thai Sharpunti $B$. gonionotus under three treatments using the different feeds like fertilizers and rice bran were studied during the experimental period. The growth parameters such as initial weight (g), cumulative weight gain $(\mathrm{g})$, weight gain $(\mathrm{g})$, percentage weight gain (\%), specific growth rate or SGR (\% per day) were recorded and shown in Table 3.

Table 3. The mean values ( \pm SD) of growth parameters among the three treatments during experimental period by using ANOVA

\begin{tabular}{|c|c|c|c|c|c|c|}
\hline \multirow{2}{*}{ Species } & \multirow{2}{*}{ Growth parameters } & \multicolumn{3}{|c|}{ Mean (+ SD) values } & \multirow{2}{*}{ F value } & \multirow{2}{*}{$\begin{array}{c}\text { Level of } \\
\text { significance }\end{array}$} \\
\hline & & $\mathrm{T}_{1}$ & $\mathrm{~T}_{2}$ & $\mathrm{~T}_{3}$ & & \\
\hline \multirow{5}{*}{$\begin{array}{l}\text { Thai } \\
\text { Sharpunti } \\
\text { (Barbodes } \\
\text { gonionotus) }\end{array}$} & Weight gain (g) & $36.24 \pm 0.96^{\mathrm{a}}$ & $65.85 \pm 1.42^{b}$ & $44.41 \pm 2.93^{\mathrm{C}}$ & 121.904 & $\star \star$ \\
\hline & Percent weight gain (\%) & $120.80 \pm 3.21^{a}$ & $219.52 \pm 4.74^{\mathrm{b}}$ & $148.03 \pm 9.76^{\mathrm{C}}$ & 121.904 & ** \\
\hline & SGR (\% /day) & $0.66 \pm 0.25^{\mathrm{a}}$ & $0.97 \pm 0.37^{b}$ & $0.77 \pm 0.42^{\mathrm{a}}$ & 108.284 & ** \\
\hline & ADG (g) & $1.28 \pm 0.12^{\mathrm{a}}$ & $2.37 \pm 0.18^{b}$ & $1.64 \pm 0.44^{a}$ & 121.904 & ** \\
\hline & Cumulative weight gain (g) & $66.24 \pm 2.93^{\mathrm{a}}$ & $95.85 \pm 1.00^{b}$ & $74.41 \pm 2.07^{a}$ & 121.904 & ** \\
\hline
\end{tabular}

** Significant at $1 \%$ level of significance

Figures in the same row with same letters are not significantly different $(P>0.01)$

Weight gain (g): The significantly $(P<0.01)$ highest growth $65.85 \pm 1.42 \mathrm{~g}$ was observed in $\mathrm{T}_{2}$ followed by $\mathrm{T}_{3}(44.41 \pm 2.93 \mathrm{~g})$ and the lowest growth $36.24 \pm 0.96 \mathrm{~g}$ was observed in $\mathrm{T}_{1}$. 


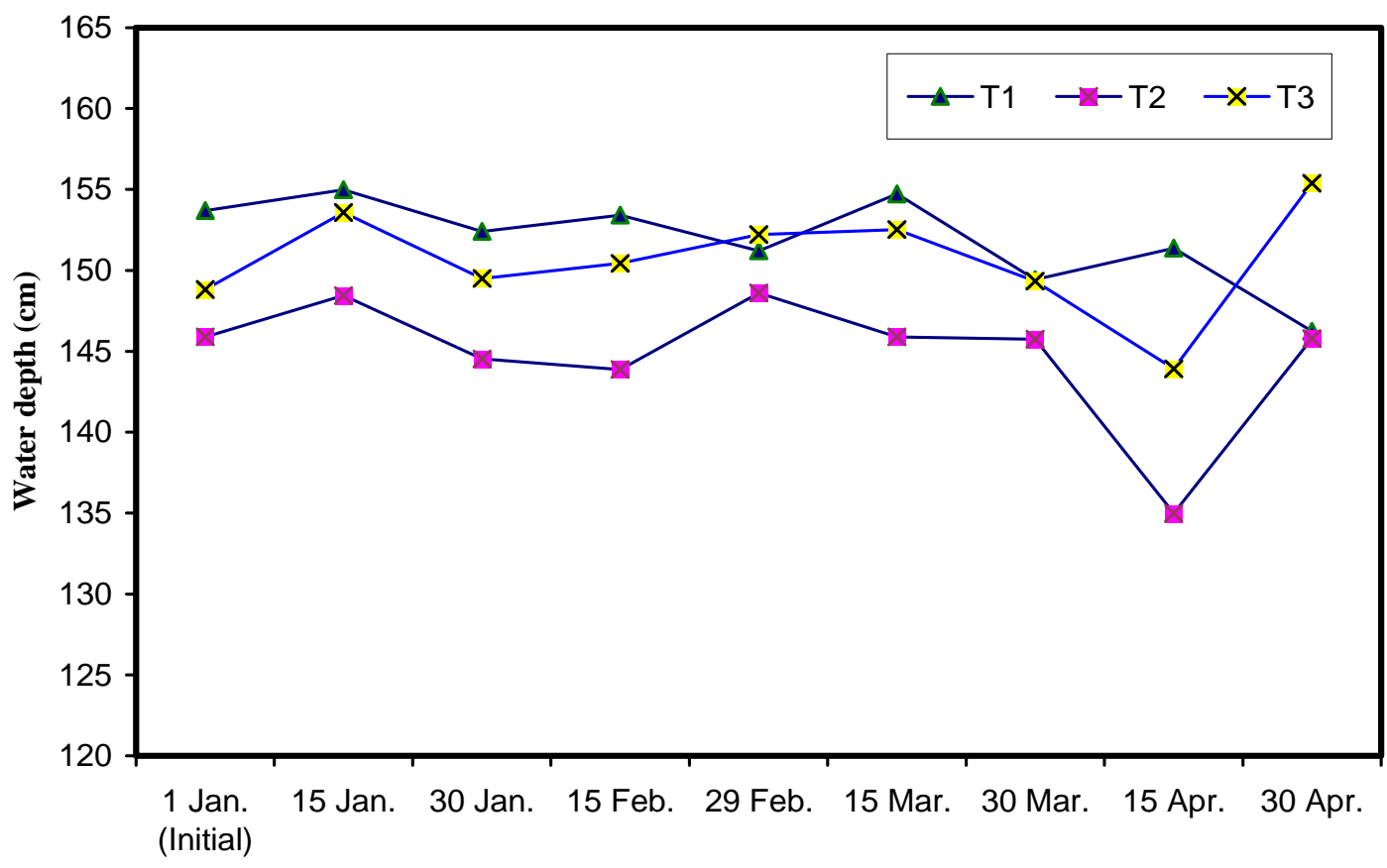

Sampling date

Fig. 1c. Showing the variations of water depth $(\mathrm{cm})$ under three treatments

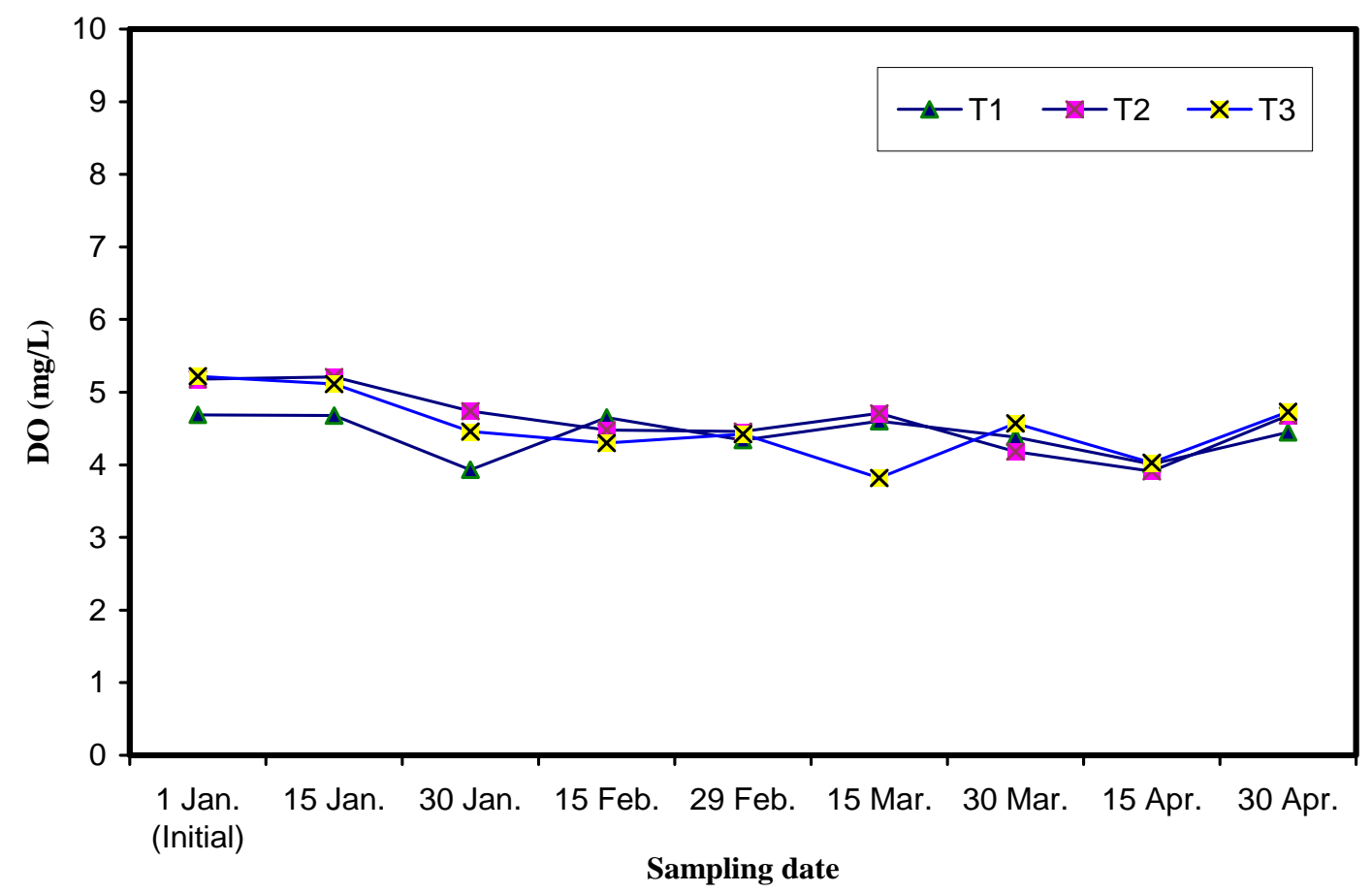

Fig. 1d. Showing the variations of dissolved oxygen (mg/L) under three treatments 


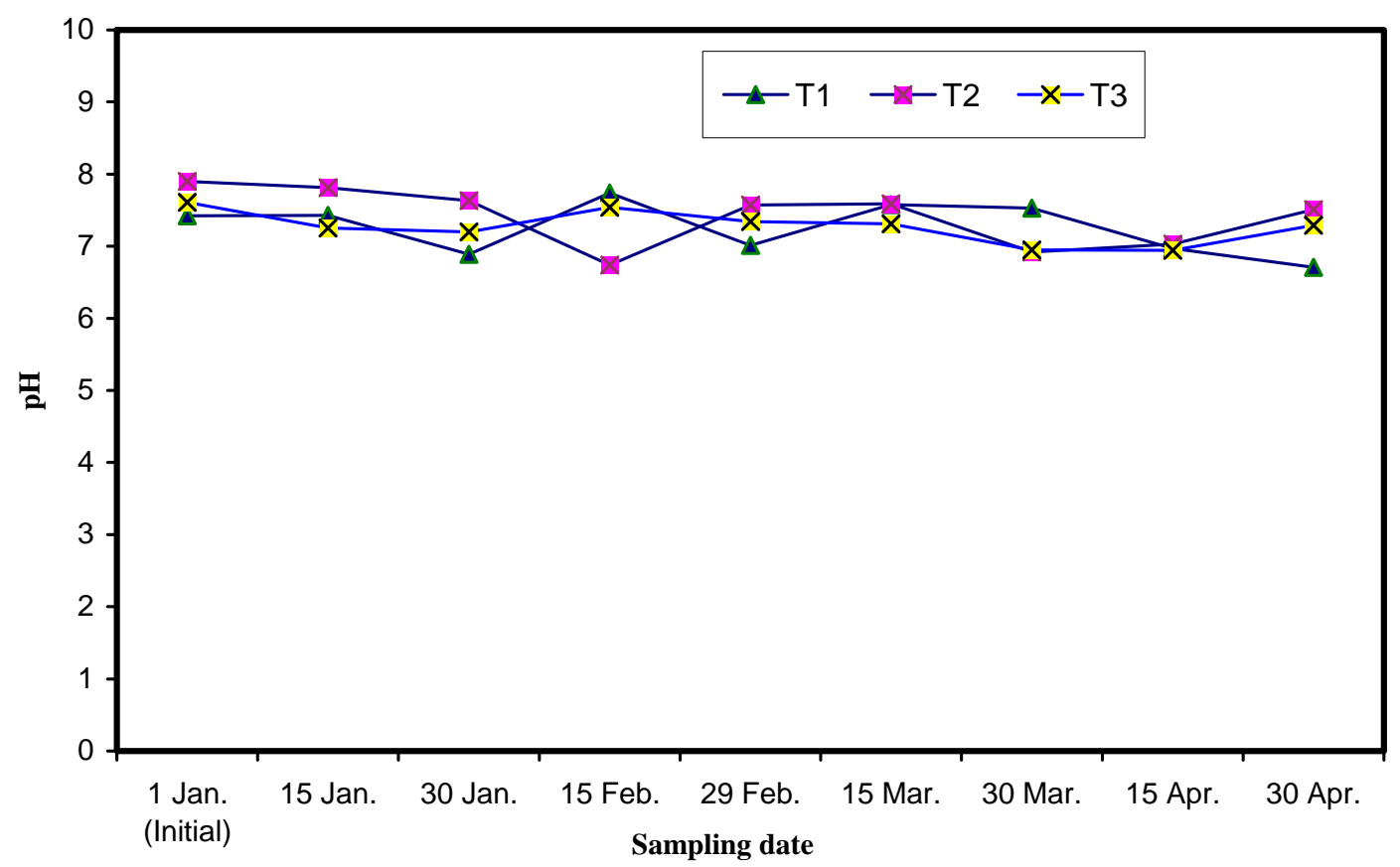

Fig. 1e. Showing the variations of $\mathrm{pH}$ under three treatments

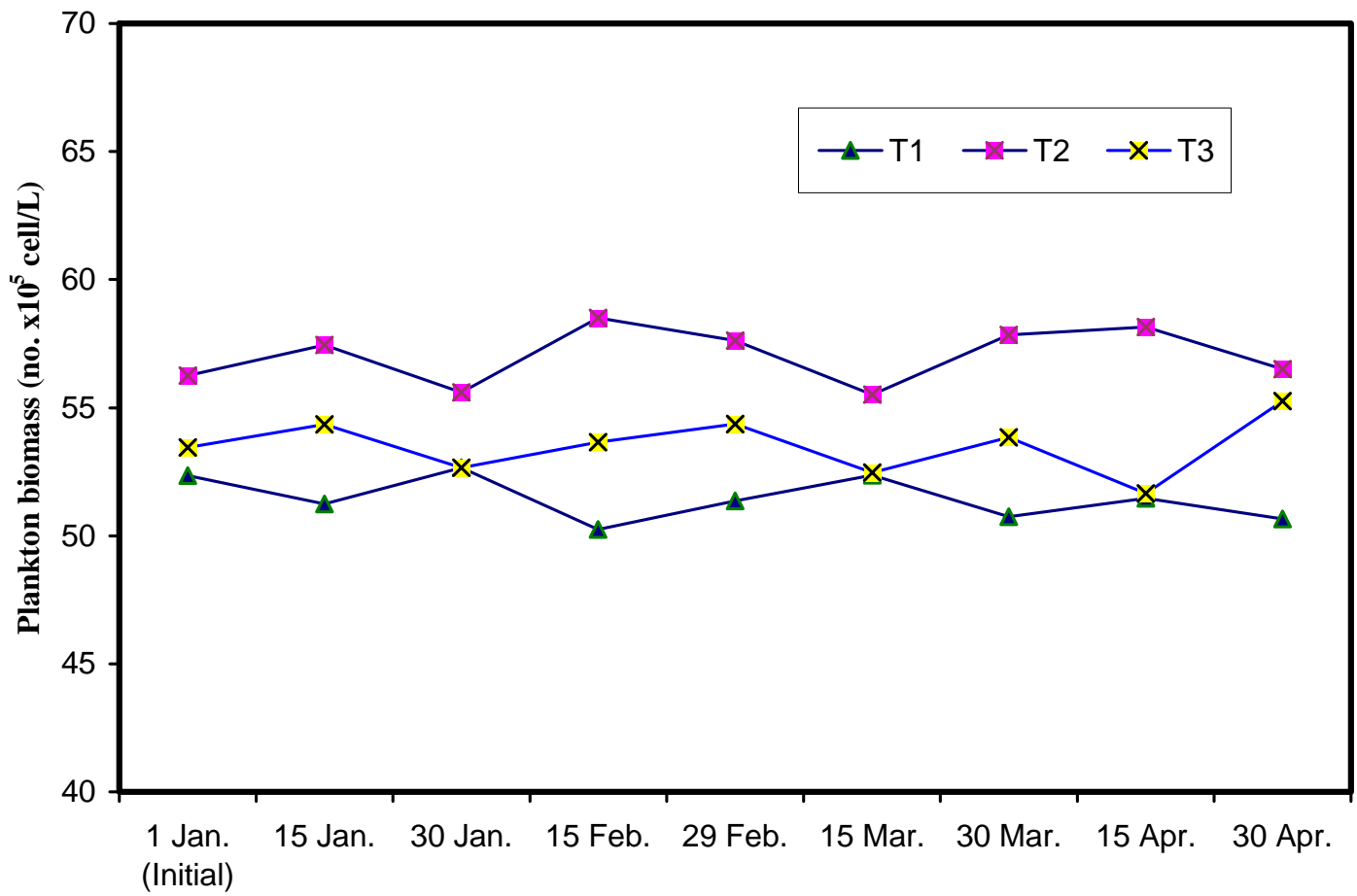

Sampling date

Fig. 1f. Showing the variations of plankton biomass (no. x10 $0^{5}$ cell/L) under three treatments 
Percentage weight gain (\%): The percent weight gain (\%) of Barbodes gonionotus in different treatments ranged from $120.80 \pm 3.21$ to $219.52 \pm 4.74$. The lowest percent weight gain was observed to be $120.80 \pm 3.21$ in $T_{1}$ while the significantly $(P<0.01)$ highest percent weight gain of $219.52 \pm 4.74$ was observed in $T_{2}$ followed by $T_{3}(148.03 \pm 9.76)$.

Specific growth rate or SGR (\% per day): The specific growth rate of $B$. gonionotus in different treatments ranged from $0.66 \pm 0.25$ to $0.97 \pm 0.37$. The lowest specific growth rate of $0.66 \pm 0.25$ was observed in $T_{1}$ while the significantly $(P<0.01)$ highest specific growth rate of $0.97 \pm 0.37$ was observed in $T_{2}$ followed by $T_{3}(0.77 \pm 0.42)$.

Average daily gain $(\mathbf{g})$ : The average daily gain $(\mathrm{g})$ of $B$. gonionotus in different treatments ranged from $1.28 \pm 0.12$ to $2.37 \pm 0.18 \mathrm{~g}$. The lowest average daily gain was $1.28 \pm 0.12 \mathrm{~g}$ observed in $T_{1}$ while the significantly $(P<0.01)$ highest average daily gain was $2.37 \pm 0.18 \mathrm{~g}$ observed in $T_{2}$ followed by $T_{3}(1.64 \pm$ $0.44 \mathrm{~g})$.

Cumulative weight gain $(\mathbf{g})$ : The cumulative weight gain of $B$. gonionotus in different treatments ranged from $66.24 \pm 2.93$ to $95.85 \pm 1.00 \mathrm{~g}$. The lowest cumulative weight gain was $66.24 \pm 2.07 \mathrm{~g}$ observed in $\mathrm{T}_{1}$ while the significantly $(\mathrm{P}<0.01)$ highest cumulative weight gain was $95.85 \pm 1.00 \mathrm{~g}$ observed in $\mathrm{T}_{2}$ followed by $\mathrm{T}_{3}(74.41 \pm 2.07 \mathrm{~g})$.

\section{Growth performance of Thai Sharpunti}

In the present study, the higher weight gain and percentage weight gain were observed in the fish of $T_{2}$ when compared with other treatments. This observation clearly indicated that Sharpunti grows rapidly when reared in the ponds regularly fertilized and rice bran is used as feed. In such situation fish gets higher plankton population in a fertilized pond and supplied rice bran and feed on. They were found to respond to fine rice bran very quickly and feed on it voraciously. Similar results were also recorded by Hepher (1971), Singh and Singh (1975) and Hussain et al. (1987).

\section{Survival rate}

The survival rates of $B$. gonionotus during the period of experiment were $89.37 \%, 94.37 \%$ and $87.50 \%$ in $T_{1}, T_{2}$ and $T_{3}$ respectively. In the present study the highest survival rate was found in $T_{2}$ (Table 5).

\section{Proximate composition of experimental diet}

The proximate composition of fine rice bran used in the experiment has been analyzed and the results are shown in Table 4 . Dry matter content was $88.14 \%$, protein content was $9.53 \%$, lipid content was $9.81 \%$, ash content was $13.59 \%$, crude fibre content was $4.76 \%$ and nitrogen free extract (NFE) was $50.45 \%$.

Table 4. Analyzed proximate composition of rice bran used in Barbodes gonionotus monoculture (\% dry matter basis) for whole experimental period

\begin{tabular}{|l|c|}
\hline Components & Percentage (\%) \\
\hline Dry matter & 88.14 \\
\hline Protein & 9.53 \\
\hline Lipid & 9.81 \\
\hline Ash & 13.59 \\
\hline Crude fibre & 4.76 \\
\hline NFE $^{1}$ & 50.45 \\
\hline
\end{tabular}

1. Nitrogen free extract calculated as $100 \%$ (moisture + crude protein + ash + crude fibre) 


\section{Total production}

Net production of Sharpunti was $462.49,888.39,555.35 \mathrm{~kg} / \mathrm{ha} / 120$ days in $T_{1}, T_{2}$ and $T_{3}$ respectively (Table 5 and Fig. 2). The net production of $T_{2}$ was significantly higher than those of $T_{1}$ and $T_{3}$. Kohinoor et al. (1993) obtained B. gonionotus production of $23.84 \mathrm{~kg} / \mathrm{ha} / 6$ months for fertilized pond along with supplemental feeding and $2,129.72 \mathrm{~kg} / \mathrm{ha} / 6$ months with only supplementary feed as rice bran. Hussain et al. (1989) obtained B. gonionotus production of $1,952 \mathrm{~kg} / \mathrm{ha} / 5$ months with only supplemental feed as rice bran and $689 \mathrm{~kg} / \mathrm{ha} / 5$ months with only fertilizers.

Table 5. Initial weight (g), stocking density, production $(\mathrm{kg} / \mathrm{ha})$ and survival rate (\%) of Thai Sharpunti in three treatments during the whole experiment

\begin{tabular}{|c|c|c|c|c|c|c|c|c|c|c|c|c|c|c|}
\hline \multirow{3}{*}{ Treatments } & \multirow{3}{*}{$\begin{array}{l}\text { Replica- } \\
\text { tion } \\
\text { No. }\end{array}$} & \multicolumn{2}{|c|}{ At stocking } & \multicolumn{5}{|c|}{ At harvesting } & \multicolumn{2}{|c|}{ Survival rate (\%) } & \multicolumn{4}{|c|}{ Total production (kg/ha/120 days) } \\
\hline & & \multirow{2}{*}{$\begin{array}{l}\begin{array}{l}\text { No. of } \\
\text { fish } \\
\text { released }\end{array} \\
\end{array}$} & \multirow{2}{*}{$\begin{array}{l}\text { Initial } \\
\text { weight } \\
\text { (g) }\end{array}$} & \multirow{2}{*}{$\begin{array}{l}\text { Final } \\
\text { weight } \\
(\mathrm{g})\end{array}$} & \multirow{2}{*}{$\begin{array}{c}\text { Net } \\
\text { increase }\end{array}$} & \multirow{2}{*}{$\begin{array}{l}\text { No. of fish } \\
\text { recovered }\end{array}$} & \multicolumn{2}{|c|}{ Total weight $(\mathrm{g})$} & \multirow{2}{*}{$\begin{array}{l}\text { Treat- } \\
\text { ments }\end{array}$} & \multirow[b]{2}{*}{ Average } & \multicolumn{2}{|c|}{ Gross } & \multicolumn{2}{|c|}{ Net } \\
\hline & & & & & & & Gross & Net & & & $\begin{array}{l}\text { Treat- } \\
\text { ments }\end{array}$ & $\begin{array}{l}\text { Ave- } \\
\text { rage }\end{array}$ & $\begin{array}{l}\text { Treat- } \\
\text { ments }\end{array}$ & Average \\
\hline \multirow[b]{2}{*}{ (57 fish/dec.) } & 1 & 80 & 30 & 65.56 & 35.56 & 73 & 4.78 & 2.60 & 91.25 & \multirow[b]{2}{*}{89.37} & 853.57 & \multirow{2}{*}{844.64} & 464.28 & \multirow[b]{2}{*}{462.49} \\
\hline & 2 & 80 & 30 & 66.92 & 36.92 & 70 & 4.68 & 2.58 & 87.50 & & 835.71 & & 460.71 & \\
\hline \multirow[b]{2}{*}{ (57 fish/dec.) } & 1 & 80 & 30 & 96.86 & 66.86 & 77 & 7.46 & 5.15 & 96.25 & \multirow[b]{2}{*}{94.37} & 1332.14 & \multirow[b]{2}{*}{1292.85} & 919.64 & \multirow[b]{2}{*}{888.39} \\
\hline & 2 & 80 & 30 & 94.85 & 64.85 & 74 & 7.02 & 4.80 & 92.50 & & 1253.57 & & 857.14 & \\
\hline \multirow{2}{*}{$\begin{array}{l}T_{3} \\
\text { (57 fish/dec.) }\end{array}$} & 1 & 80 & 30 & 76.48 & 46.48 & 69 & 5.28 & 3.21 & 86.25 & \multirow[b]{2}{*}{87.50} & 942.86 & \multirow[b]{2}{*}{930.36} & 573.21 & \multirow[b]{2}{*}{555.35} \\
\hline & 2 & 80 & 30 & 72.34 & 42.34 & 71 & 5.14 & 3.01 & 88.75 & & 917.86 & & 537.50 & \\
\hline
\end{tabular}

In the present study, the result showed that $B$. gonionotus when cultured in combination with rice bran (fine) and fertilizer gave best growth performance in terms of weight gain $65.85 \pm 1.42 \mathrm{~g}$ in a culture period of 4 months.

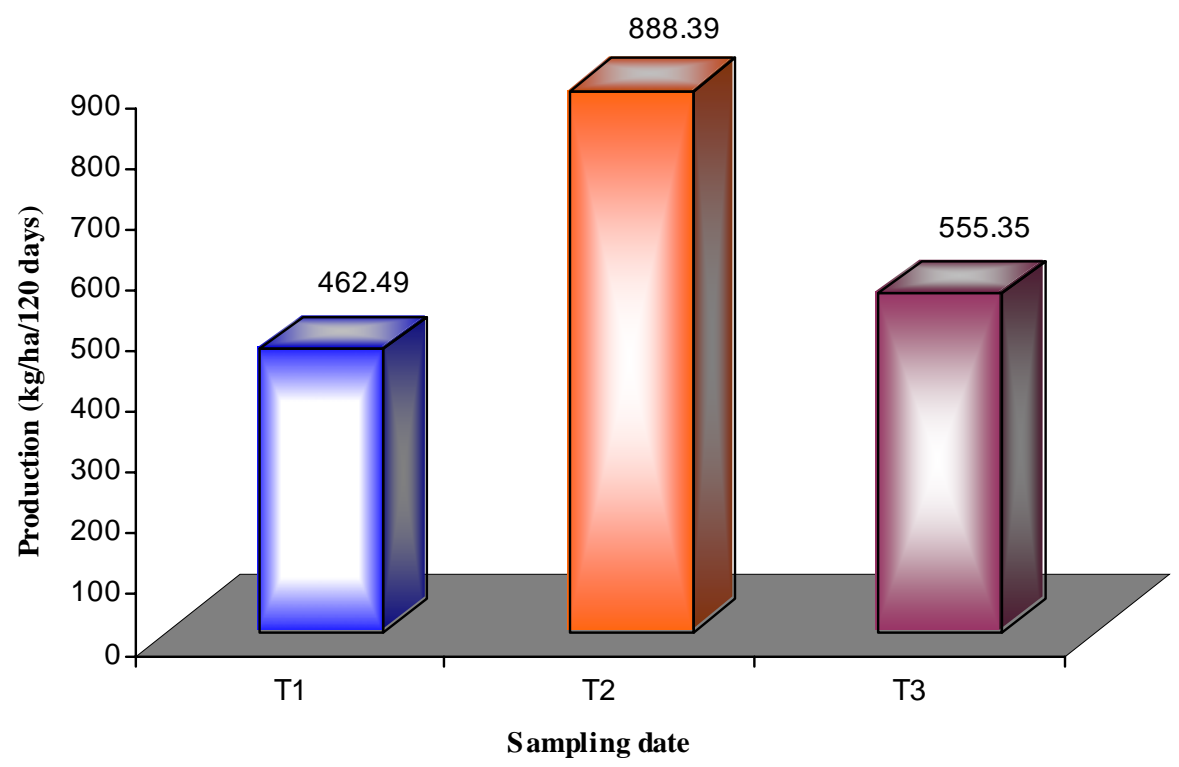

Fig. 2. Showing the net production (kg/ha/120 days) of Barbodes gonionotus 


\section{References}

Ali, S., Ataur Rahman, A.K., Patwary, A.R. and Islam, K.H.R. 1982. Studies on the diurnal variations in physico-chemical factors and zooplankton in freshwater pond. Bangladesh J. Fish., 2-5 (1-2): 15-23.

Alikunhi, K., 1957. Fish culture in India. Farm Bull Indian Coun. Agric. Res., 20: 144.

AOAC (Association of Official Analytical Chemicsts), 1980. Official methods of analysis Association of Official Analytical Chemists, W. Howritz (Editor), 13 ${ }^{\text {th }}$ edition. Washington, D. C. $1018 \mathrm{pp}$

Balarin, J.D. and Haller, R.D. 1982. The intensive culture of Tilapia in tanks, receways and cages. In; J. F. Muni and R. J. Robers (eds.) Recent advances in aquaculture, Croom, Helm Itd., 2-10 St. Johnis Road, London Sw. 11.

Banerjea, S.M. 1967. Water quality and soil condition of fish ponds in some States of India in relation to fish production. Indian J. Fish 14: 115-144.

Coche, A.G. 1967. Fish culture in rice field. A World wide Synthesis. Hydrobiologia, 30: 1-44.

Dewan, S. 1973. Investigation into the ecology of fishes of a Mymensingh lake. A. Ph. D. Thesis, Faculty of Fisheries. Bangladesh Agricultural University, Mymensingh. 145-147 pp.

Hepher, B. 1971. Ten years of research in fish pond fertilization in Israel. II. Fertilization dose and frequency of fertilization. Bamidgeh, 15 (4): 78-92.

Hussain, M.G., Akhteruzzaman, M., Karim K.A.T.A. and Shah, M.S. 1989. Semi-intensive culture of Puntius gonionotus. Bangladesh. J. Fish. 12 (2): 45-52.

Hussain, M.G., Rahman, M.M. Akteruzzaman and Perschalbacher, P. 1987. Hormone induced ovulation and spawning of Puntius gonionotus (Bleeker). Bangladesh J. Fish., 10 (10): 1-4.

Islam, A. 1996. A report on aquatic culture in Bangladesh. Fish Inf. B. Bangladesh Fish. Res. Sy. System, 1 (2): 1-28.

Keilhorn, W.V. 1952. The biology of the surface zone Zooplankton of a Boreo-Arctic Atlantic Ocean Area. J. Fish Res. Board. Canada. 9: 223-264.

Kohinoor, A.H.M., Akhteruzzaman, M. and Sahah, M.S. 1993. Production of Puntius gonionotus (Bleeker) in ponds. Bangladesh J. Zool., 21 (2): 77-83.

Monju, S. 1996. Experiment on the Rearing Techniques of Thai sharpunti (Puntius gonionotus). M. S. Thesis, Department of Fisheries Management, Bangladesh Agricultural University, 1-3 pp.

Rahman, M.S. 1992. Water quality management in Aquaculture. BRAC PROKASHANA 66, Mohakhali, Dhaka - 1212. Bangladesh. 75 pp.

Rahman, M.S., Chowdhury, M.Y., Aminul Haq, M.S. 1982. Limnological studies of four ponds. Bangladesh J. Fish., 25 (1-2): 25-35.

Singh, C.S. and Singh, K.P. 1975. Feeding experiments on Indian major carps in Taria ponds. J. Indian Fish. Soc. India, 7: $212-215$.

Sreenivasan, A. 1976. Limnological studies and primary production in temple pond ecosystems. Hydrobiologia., 48 (2): $117-123$. 